DOI:http://dx.doi.org/10.18524/1810-4215.2019.32.182523

\title{
INTERNATIONAL NUCLEAR DATA CENTERS NETWORK AND PROSPECTS OF ITS USE IN NUCLEAR POWER IN BELARUS
}

\author{
I.A. Serenkova ${ }^{1}$, A.A. Pankov ${ }^{1,2,3}$ \\ ${ }^{1}$ Abdus Salam ICTP Affiliated Centre at Technical University of Gomel, \\ Gomel 246746 Belarus inna.serenkova@cern.ch \\ ${ }^{2}$ Institute for Nuclear Problems of Belarusian State University, \\ Minsk, 220030 Belarus \\ 3 Joint Institute for Nuclear Research, \\ Dubna, 141980 Russia apankov@jinr.ru
}

\begin{abstract}
We give a brief overview of the existing nuclear data base, and describe the structure of the International Nuclear Data Centres Network. Because the amount of experimental data in nuclear physics is extremely large, the note aims to show the way to modern methods of acquaintance with the characteristics of arrays of nuclei through the nuclear data banks accessible through the Web-technologies. In particular, the note describes the methods to extract information on the nuclei and nuclear reactions in nuclear data banks. The data include information on the masses and energies of the nuclei of the separation energy of nucleons and clusters, the spectra of states of nuclei, their spin, parity, isospin, charge and mass radii and densities, information about the shape of the nuclei, the cross sections of nuclear reactions, the decay of unstable nuclei. On the completeness and accuracy of the data depends on radiation and nuclear safety, and environmental acceptability of nuclear installations. Creating a nuclear databases in Belarus will monitor the quality of nuclear data supplied to consumers, and ensure that systems of constants, used in technical projects, the current international standards.
\end{abstract}

Keywords: nuclear data centre, nuclear power.

АНОТАЦЯЯ. Дається короткий огляд існуючих баз ядерних даних та міжнародної мережі центрів ядерних даних. Оскільки обсяг експериментальних даних по фізиці ядра надзвичайно великий, в роботі наводяться сучасні методи ознайомлення 3 масивами характеристик ядер через банки ядерних даних. Зокрема, описані методи вилучення інформації про ядра i ядерні реакції через банки ядерних даних. Дані включають в себе інформацію про маси і енергї зв'язку ядер, про енергії відділення нуклонів і кластерів, спектрах станів ядер, їх спинах, парності, ізоспінам, зарядових і масових радіусах і щільності, інформацію про форму ядер, перетинах ядерних реакцій, розпади нестабільних ядер. Від повноти i точності цих даних залежать радіаційна i ядерна безпека, а також екологічна прийнятність ядерних установок. Створення бази ядерних даних в Білорусі дозволить контролювати якість ядерних даних, що поставляються споживачам, i забезпечити відповідність систем констант, які закладаються в технічні проекти, сучасним міжнародним стандартам. На основі інформації, що містяться в базах ядерних даних, оцінюється радіаційне навантаження на корпуси реакторів AEC i інші вузли в процесі їх експлуатації. Це дозволяє контролювати процес безпечної експлуатації корпусів атомних реакторів i оцінювати можливість продовження ресурсу експлуатації, якщо перевищує межі регламентного терміну. Результати досліджень, отримані в представленій роботі, були частково використані при визначенні та уточненні кола завдань, що вирішуються при виконанні спільних НДР в рамках Договору про науково-технічному співробітництво між Інститутом ядерних досліджень НАН України (м. Київ), ДНУ «Об'єднаний інститут енергетичних і ядерних досліджень - Сосни» НАН Білорусі (ОІЕЯД - Сосни) і УО «Гомельський державний технічний університет ім. П.О.Сухого».

Ключові слова: бази ядерних даних, міжнародна мережа центрів ядерних даних, бази ядерних даних в Білорусі. 
1. Introduction. Nuclear Data Types and Data Centers

\subsection{What is nuclear data?}

Nuclear data are quantitative results of scientific investigations of the nuclear properties of matter. They describe properties of atomic nuclei and the fundamental physical relationships governing their interactions, thereby characterizing the physical processes underlying all nuclear technologies. Examples of nuclear data include cross sections, half-lives, decay modes and decay radiation properties, and $\gamma$-rays from radionuclides. The scope of the data collections includes all 85 natural elements with 290 stable isotopes and more than 2500 radionuclides.

The applications of nuclear data include all areas of nuclear science and technology, covering energy applications (fission reactor design; nuclear fuel cycles; nuclear safety; reactor monitoring and fluence determination; waste disposal and transmutation; accelerator driven systems; fusion device design and plasma processing technologies) as well as non-energy applications (cancer radiotherapy; production of radioisotopes for medical and industrial applications; personnel dosimetry and radiation safety; nuclear safeguards; waste disposal and transmutation; environmental monitoring and clean-up; materials analysis and process control; radiation damage studies; detection of concealed explosives and illegal drugs; exploration for oil and other minerals) and basic research (e.g. nuclear astrophysics) and education. For details of the review of nuclear data for applications and original references, see Tsytrinov A.V., Pankov A.A., Serenkova I.A.: 2015.

\subsection{The role of the IAEA Nuclear Data Section}

The Nuclear Data Section (NDS) of the International Atomic Energy Agency (IAEA) carries out the IAEA activities concerning development and dissemination of nuclear and atomic data for applications. In addition, the NDS is involved in technology transfer activities to assist scientists in developing countries.

The main tasks of the data center include compilation of new data in the databases EXFOR and CINDA (in cooperation with other participating data centers, see below), collection and maintenance of generalpurpose and specialized evaluated data libraries, online and off-line nuclear data services with particular emphasis on the needs of developing countries, and coordination of nuclear data center networks.

Nuclear data development is conducted mainly through Co-ordinated Research Projects (CRPs). In such projects, which usually result in the production of a new (or significant upgrade of an existing) database, typically $4-10$ scientific groups from different countries work together under IAEA contracts or agreements over a period of 3-4 years.

Technology transfer to developing countries is carried out in two ways: through Technical Co-operation projects, such as the recent "Latin American Mirror Server Project" providing online nuclear data service to Latin American countries with insufficient Internet connection to the NDS, by installing a mirror server in Brazil, or the installation of a "mini data center" on a workstation in Ghana; and through nuclear data workshops such as those held at ICTP Trieste.

The Atomic and Molecular Data Unit of the NDS keeps databases for fusion energy and other plasma research and other applications, such as ALADDIN (numerical data) and AMBDAS (bibliographic data), and issues specialized publications (e.g. CIAMDA). The databases are kept on a separate server. The remainder of this lecture deals only with the nuclear data services of NDS.

\subsection{Nuclear data types}

Nuclear data are commonly categorized in two main groups: nuclear reaction data, describing the interactions of various projectiles such as neutrons, protons or photons with target nuclei, and nuclear structure and decay data, describing nuclear levels, half-lives and radioactive decay radiations. For evaluated data (both numeric) or bibliographic.

Bibliographic data: References with some description of the contents, but no numerical data. Examples are CINDA (Computer Index of Neutron Data) and NSR (Nuclear Science References).

Experimental data: Results of individual measurements as reported by the authors. The most important example is EXFOR/CSISRS, the library for experimental nuclear reaction data.

Evaluated data libraries contain recommended data based on all data available from experiments and/or theory, arrived at after critical analysis of experimental data and their uncertainties, inter- and extrapolation, and/or nuclear model calculations. They are stored in strictly defined formats such as ENDF-6 (the international format for evaluated nuclear reaction data) or ENSDF (the format of the Evaluated Nuclear Structure data File). The main cross section libraries in ENDF format usually also contain the relevant decay data needed in the main applications.

Nuclear reaction data include cross sections, angular and energy distributions of secondary particles, resonance parameters, and related quantities. For neutron-induced reactions up to $20 \mathrm{MeV}$, the libraries are very complete; the coverage for higher energies is less complete but improving. Experimental data are found in EXFOR, the related bibliography in CINDA; several evaluated data libraries exist up to $20 \mathrm{MeV}$ or 
higher. For charged-particle induced and photonuclear reactions, selected experimental data are compiled in EXFOR and only few evaluations exist. Heavy-ion data are partly compiled in EXFOR.

Nuclear Structure and decay data: Half-lives, decay schemes, nuclear level properties, energies and intensities of $\gamma$-rays and emitted particles, atomic masses. The major database is ENSDF, related bibliographic data are contained in NSR. There are many other nuclear structure and decay data libraries, mostly derived from or related to ENSDF; some of these are listed in Section 2 below, others - not available from NDS - include the Table of Isotopes, the Isotope Explorer, a computer program for viewing ENSDF and for interactive access to nuclear structure and decay data, and NUBASE, a library of nuclear and decay properties.

\subsection{Nuclear data center networks}

Both the collection and the distribution of nuclear data are organised on a world-wide scale. Two international networks are coordinated by the IAEA: the Network of Nuclear Reaction Data Centers and the Nuclear Structure and Decay Data Network. The data centers participating in these networks are involved in the various stages of data preparation between measurement and application (i.e. compilation, review and/or evaluation, processing, distribution). Specialized data centers cooperate with the major centers in the various data center functions (in particular data compilation and evaluation). The sharing of work on a world-wide basis in the various areas of work, including data distribution, is defined partly geographically and partly by data types (scope) and is coordinated by the IAEA Nuclear Data Section.

\section{Overview of Data Libraries at IAEA}

The IAEA Nuclear Data Section holds a total of about 100 nuclear data libraries, representing an enormous economic and scientific value. All libraries and the related documentation are available free of charge to scientists in IAEA member states. An overview is given in the document Index of Nuclear Data Libraries available from the IAEA Nuclear Data Section. Brief documentations of contents and/or format for most libraries are published in the IAEA-NDS- report series.

\subsection{General purpose libraries}

Nuclear Wallet Cards: Basic properties of ground and meta-stable states, available as a pocket booklet (from US-NNDC) and online.

NUDAT: User-friendly extract of most important data (for applications) from ENSDF, plus thermal neutron data (cross sections and resonance integrals). Available online.

MIRD: "Medical Internal Radiation Dose": Based on ENSDF, data processed with code "RADLST". Tables with intensities, energies and dose of all produced radiations, including X-rays, Auger electrons, etc., and decay scheme plots, for the selected nuclide. Available online.

ENSDF: (Evaluated Nuclear Structure Data File) is the "master library" for structure and decay data, resulting from a continuous international evaluation effort coordinated by the IAEA. The master file is maintained by the US-NNDC. It contains evaluated experimental data for most known nuclides in the mass range 1 - 277. The evaluations are done for mass chains (e.g. $\mathrm{A}=235$ ) and are published in the journal Nuclear Data Sheets. Available online.

NSR: (Nuclear Science References): Bibliographic database for low and intermediate energy nuclear physics. This is the main bibliography for structure and decay data and for non-neutron reaction data and covers the literature from 1910 to present. It is published regularly in the journal Nuclear Data Sheets Available online.

CINDA: (Computer Index of Neutron Data): Bibliography of neutron data literature, covering also inofficial publications and computer files. Includes also $(\gamma, 11),(\gamma, \mathrm{f})$ and spontaneous fission data. References describing the same experiment are listed together. An extension of the database to include charged-particle induced and all photonu- clear reactions is under preparation. Available online, as a book in several volumes, and on CD-ROM

EXFOR: Experimental nuclear reaction data, compiled continuously by the network of nuclear reaction data centers coordinated by NDS. Contains neutron, charged-particle induced and photonuclear data, including integral and all types of differential cross sections, resonance parameters, polarization data, fission product yields, and many related data types. The library contains both numerical data tables and a structured abstract with experimental and bibliographic information. The neutron data in EXFOR are linked to the CINDA bibliography. The data can be retrieved in several formats, including computational format for further processing, and graphs. The main usage of EXFOR is for evaluators (the EXFOR database is the starting point for all cross section evaluations), for applied users if no evaluation is available, and for researchers measuring or calculating cross section data. Available online and on CD-ROM.

Evaluated cross section data libraries in ENDF-6 format: the major "general purpose" evaluated libraries ENDF-B/VI (USA), BROND-2 (Russia), JEF-2 (Europe), JENDL-3 (Japan), CENDL-2 (China) are available online ("ENDF" database) and 
on CD-ROM. All of these libraries cover the neutron energy range from $10^{-5} \mathrm{eV}$ to $20 \mathrm{MeV}$, with some evaluations extending to higher energies (partly up to $1 \mathrm{GeV}$ ) and including also some charged-particle induced reactions. Output is available in several formats including plots, and software packages (Pre-Processing and Utility codes) are available for data treatment. Online comparisons of evaluated and experimental cross sections can be done using the package ZVView.

\subsection{Specialized evaluated cross section libraries}

FENDL-2: Comprehensive cross section library for fusion and other applications, resulting from a worldwide effort including extensive testing, coordinated by IAEA consists of several sublibraries for transport calculations, activation, fusion reactions, etc. Available online.

IAEA Photonuclear Data Library: Evaluated photonuclear cross sections for $\mathbf{1 6 4}$ isotopes for energies up to $140 \mathrm{MeV}$ (most isotopes), up to about $\mathbf{2 5}$ $\mathrm{MeV}$ for the others; for shielding, medical and other applications. Available online.

Charged Particle Cross Section Database for Medical Radioisotope Production for diagnostics and monitor reactions: Production cross sections for $\gamma$ emitters and positron emitters, for incident protons through a-particles up to about $30 \mathrm{MeV}$. Available online.

RNAL (Reference Neutron Activation Library): Evaluated cross sections for 255 neutron-induced reactions leading to radioactive products, for activation analysis and various other applications. The evaluations were extracted from various regional and national projects.

NGATLAS: Atlas of neutron capture cross sections for 739 targets from $10^{-5} \mathrm{eV}$ to $20 \mathrm{MeV}$. Available as a handbook (plots only) or online.

RRDF-98 Neutron cross sections for 22 dosimetry reactions. Available online.

MENDL-2 and MENDL-2P Activation cross sections for 505 stable and unstable targets between A1 and Po for incident neutrons up to $100 \mathrm{MeV}$ and incident protons up to $200 \mathrm{MeV}$, for transmutation and other applications. Available by FTP.

WIND and WIND-2 Cross sections for U, Np, and $\mathrm{Pu}$ isotopes for waste incineration, including neutron cross sections up to $100 \mathrm{MeV}$, proton cross sections for $U^{238}$, and neutron activation data for $P u^{239}$ up to $2 \mathrm{GeV}$.

Minsk Actinides Library Evaluated neutron cross sections for $\mathrm{Th}^{232}$, U, Np, $\mathrm{Pu}, \mathrm{Am}$ and $\mathrm{Cm}$ isotopes.

\subsection{Other special libraries}

RIPL-2 A database of input parameters for nuclear model calculations of nuclear reaction data, available online.

NMF-90 Neutron Metrology File: Integrated database for neutron spectrum adjustment (unfolding) calculations. Available online.

XG Standards(X-ray and $\gamma$-ray standards for detector calibration): This database contains for selected nuclides their half-lives and the energies and emission probabilities of $\gamma$-rays and X-rays suitable for detector and efficiency calibration. A new version will be released soon, see NDS web page.

EPDL9T (Evaluated Photon Data Library): Photon interaction data from $1 \mathrm{eV}$ to $100 \mathrm{GeV}$ from Lawrence Livermore National Laboratory.

SGNucDat (Nuclear Data for Safeguards): A PC database (also available as a handbook) containing nuclear data needed for the development and application of nuclear material accounting techniques.

\subsection{Computer programs}

The following computer code packages are available free of charge from NDS.

EMPIRE-II: system of codes for nuclear reaction calculations (Version 2.18);

ENDF Utility Codes (Release 6.13);

ENDF Preprocessing Codes (PREPRO 2015);

ENDVER: ENDF Verification support package;

ENSDF analysis and utility programs;

ZVVIEW package for interactive plotting of nuclear data.

Other computer codes for the processing of nuclear data have to be requested from the NEA Nuclear Data Bank, Issy-les-Moulineaux near Paris, France.

\section{Data Access and Services}

Various data distribution media are offered by NDS, including WWW, CD- ROM and hardcopies in order to serve the diverse needs of users from both developing and fully industrialized counties. A nuclear data "mirror server" has been established at IPEN in Brazil to improve on-line access for Latin America by providing WWW, FTP and Telnet access to the IAEA nuclear data services.

WWW: "Nuclear Data Services" website of the IAEA can be accessed through http://www-nds.iaea.org (IAEA Vienna) or http://www-nds.ipen.br/ (Brazil mirror server). Contains links to most data libraries, electronic documents, nuclear data programs, general information, 
and much more. Some data are available also by FTP and/or a Telnet-based on-line retrieval system.

Handbooks: A number of nuclear data handbooks have been produced by NDS (some of them are priced IAEA publications), including hardcopy versions of the CINDA bibliography of neutron data, and a Handbook on Nuclear Data for Safeguards; normally, the results of a Co-ordinated Research Project on nuclear data are published within the IAEA-TECDOC series.

Reports: NDS publishes informal reports in the INDC series, containing meeting summaries, unpublished nuclear data works from member states, and translations from Russian literature; most recent reports are available electronically on the NDS website.

Nuclear Data Newsletter is published biannually, and serves as the primary medium for current awareness of new nuclear data available from NDS; available in hardcopy and from the web.

Custom retrievals and other mail services can be requested by informal e-mail to services@iaeand.iaea.org.

\section{Creation of a nuclear data center at Gomel State Technical University (GSTU)}

The activity on the development of Scientific, Methodological and Information Basis for Nuclear and Technological Calculations had been started in 2013 in the framework of joint Project of Ukrainian Nuclear Data Center (UkrNDC) at the Institute for Nuclear Research of NAS (Ukraine) and Laboratory for Physical Studies at the GSTU (Gomel, Belarus). The name of the Project was "Accumulation, Processing, Systematization and Analyses of Information in the Nuclear Power as the basis to found the Information Nuclear Data Center".

Fourteen Webpages of the Nuclear Data Information Center (in Russian and English) at GSTU were developed and performed by Dr. O.O. Grizay. In most cases, the Russian and English versions of the pages are identical, with the exception of the "MANUAL" pages. The main Webpage is depicted in Fig. 1.

\section{Concluding Remarks}

The primary aims of the IAEA Nuclear Data Section are to encourage the development and organize the assembly of a wide range of atomic and nuclear databases, and ensure improvements in technical performance by providing ready access to users in Member States. To make the service more userfriendly and, at the same time, extend the retrieval possibilities, development of a combined nuclear reaction database is under way, using advanced database software, with which the EXFOR, CINDA and ENDF

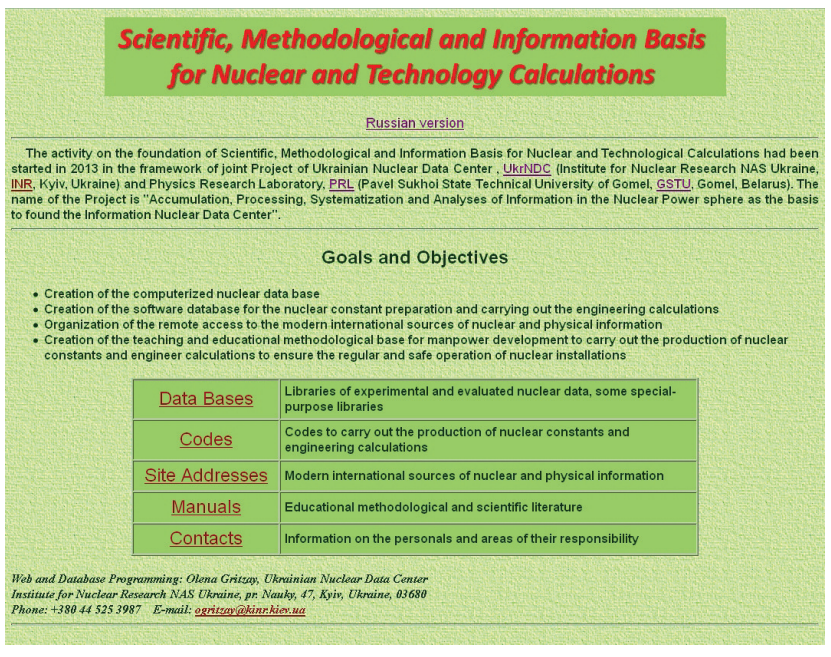

Figure 1: Main Webpage (in English) of the Nuclear Data Information Center at the GSTU.

libraries will look like one database to the user. Further improvements under way include increased distribution of databases through the Internet and the creation of additional regional copies of the "Nuclear Data Services" Websites. Creating a nuclear databases in Belarus, in particular in GSTU (Gomel) in closed collaboration with Ukrainian experts is also discussed.

Acknowledgements We would like to thank Dr. O.O. Grizay and Dr. O.I. Kalchenko for the enjoyable collaboration on the subject matter covered here.

\section{References}

Pankov A.A., Tsytrinov A.V., Serenkova I.A.: 2015, Nonlinear Dynamics and Applications., 21, 270. 